\title{
Agronomic Evaluation and Genetic Variation of Tunisian Tall Fescue (Festuca arundinacea Schreb.)
}

\author{
N. Chtourou-Ghorbel, ${ }^{1}$ M. Chakroun, ${ }^{2}$ H. Elazreg, ${ }^{1}$ and N. Trifi-Farah ${ }^{1}$ \\ ${ }^{1}$ Laboratoire de Génétique Moléculaire, Immunologie et Biotechnologie, Faculté des Sciences de Tunis, Campus Universitaire, \\ El Manar, Tunis 2092, Tunisia \\ ${ }^{2}$ Laboratoire des Productions Animales et Fourragères, Institut National de la Recherche Agronomique de Tunisie, \\ Rue Hédi Karray, Ariana 2049, Tunisia
}

Correspondence should be addressed to N. Chtourou-Ghorbel, nidhal.ghorbel@hotmail.fr

Received 11 March 2011; Accepted 13 May 2011

Academic Editor: Tom Stalker

Copyright (C) 2011 N. Chtourou-Ghorbel et al. This is an open access article distributed under the Creative Commons Attribution License, which permits unrestricted use, distribution, and reproduction in any medium, provided the original work is properly cited.

\begin{abstract}
Nine important agronomic traits were used to assess the genetic diversity of Tunisian tall fescue and to investigate the extent of genotype X environment (GE) interaction and its implications for breeding programs. These traits were studied for three consecutive years in thirty-five spontaneous populations and three cultivars. Panicle size contributed to seeds production, while the plant height at harvest and dry matter yield were selected for forage performance. Analysis of variance demonstrated that population attitude depended on the year and environmental conditions. Principal component analysis revealed significant similarities among some spontaneous populations and cultivars. The relationship between environmental conditions and agronomic traits revealed the influence of altitude, soil texture and minimum temperature on forage production, seed yield, and the architecture of plants, respectively. In addition, the local adapted ecotypes originating from Bizerte, Sidi Nsir, and Rass Rajel attained greater agronomic potentialities than control cultivars and were of considerable economic interest for the improvement of Tunisian tall fescue.
\end{abstract}

\section{Introduction}

Festuca L. is one of the largest genus in the Poaceae family with more than 400 species. The Tunisian natural flora is rich in diverse forage and pasture species including tall fescue $[1,2]$. Tall fescue (Festuca arundinacea Schreb.), a perennial hexaploid species $(2 n=6 x=42)$ [3], has many positive agronomic characteristics and is widely used as a forage, pasture, and turf grass in the temperate and Mediterranean climates [4]. The species has many useful qualities but fails to provide sufficient energy for optimum animal performance, primarily because of modest digestibility (this depends on maturity). Its ability to grow on wet soils, to tolerate both alkalinity and salinity, and to produce heavy turf makes it an excellent grass for marginal sites for either forages or soil conservation purposes. In addition, tall fescue can be used flexibly in various farming systems, as it can be cultivated in monoculture or in association with legumes, in mixture with other grasses, grazed or cut, and made into hay or silage [5].
Excellent fall growth potential of Tunisian hexaploid accessions indicates that they might provide useful germplasm for breeding programs when crossed with European tall fescue [6].

In Tunisia, these phylogenetic resources are currently being lost due to severe genetic erosion associated overgrazing, irregular rainfall, and the loss of rangeland. Therefore, a survey of the genetic diversity in Tunisian tall fescue is necessary to encourage rational management and selection programs involving the local tall fescue germplasm.

Genotype and environment are major determinants of plant phenotype [7] and expressed by phenotypic differentiation that occurs in grass species from ecologically adjacent sites [8-10]. The objective of this study was to assess the genetic variation and the agronomic performance of a set of Tunisian tall fescue ecotypes and analyse the influence of pedoclimatic factors on agronomic traits. This investigation, undertaken for the first time in Tunisia, provides a tool allowing plant breeders to select the most promising populations 
by taking into account population-environment interactions [11].

\section{Materials and Methods}

Thirty eight accessions were analyzed in this study. They consisted of 35 spontaneous populations collected from the North, North East and North West of Tunisia in 1994 (Figure 1) and three local cultivars "Mornag," "Grombalia," and "Jebebina."

This plant material, collected from 35 sites in Tunisia, represents many geographic origins and pedoclimatic characteristics of the populations (Table 1).

A field trial was established in September 2004 in Sejnane ("Institut National de la Recherche Agronomique de Tunisie" INRAT experimental station, Tunisia). A bulk of 40 seedlings transplanted into plots was used from each population. Each plot consisted of four rows $0.5 \mathrm{~m}$ apart with 10 seedlings, spaced $0.25 \mathrm{~m}$ apart, within rows. The trial was carried out during three consecutive years (2005-2007).

Nine agronomic traits were scored for each of the 38 accessions. The characters studied were related to yield components consisting of seed or forage production [12]. In each year and from each accession plot, 30 randomly selected panicles were generally sampled to determine: panicle length (PL), panicle weight (PW), spikelet number per panicle (SN), and panicle weight without seeds (PS). Forage yield was harvested at anthesis (in April for each year) from the two center rows of each population. A random $500 \mathrm{~g}$ sample was collected from the harvested green matter of each plot and dried at $70^{\circ} \mathrm{C}$ for dry matter yield (MY) determination. After harvest, plots were fertilized with $100 \mathrm{~kg} \mathrm{ha}^{-1} \mathrm{~N}$ and left for seed production. Seed was harvested in bulk from the remaining rows of each population, threshed, cleaned, and weighed. In addition, plant height at harvest $(\mathrm{PH})$, weight of 10 panicles (TP), seed yield (SY), and 100 seeds weight (SW) were measured in this study.

Eight pedoclimatic factors consisting of altitude (AL), rainfall (RF), slope incline (SI), anthropogenic disturbances (AD), soil $\mathrm{pH}$, soil texture (ST), minimum temperature $(\mathrm{mT})$, and maximum temperature (MT) were recorded at each sites (Table 1$)$. Soil pH (10 cm depth) was determined using an Inoculo kit $\left(\mathrm{H}_{2} \mathrm{O}\right.$ equivalent) and annual rainfall was estimated using regional rainfall maps for each site.

For statistical analysis, data were analysed using the SAS Software (Statistical Analysis System) [13]. Analysis of variance using the ANOVA procedure (Single factor ANOVA) was performed on the four agronomic characters: PL, SN, PW, and PS that characterize each individual per population. A principal component analysis (PCA) was performed on the nine agronomic traits [14]. Then, a factorial correspondence analysis (FCA) was established on the base of the agronomic characters and the pedoclimatic factors.

\section{Results and Discussion}

Analysis of variance revealed that populations differed significantly $(P<.001)$ for all four measurements and the

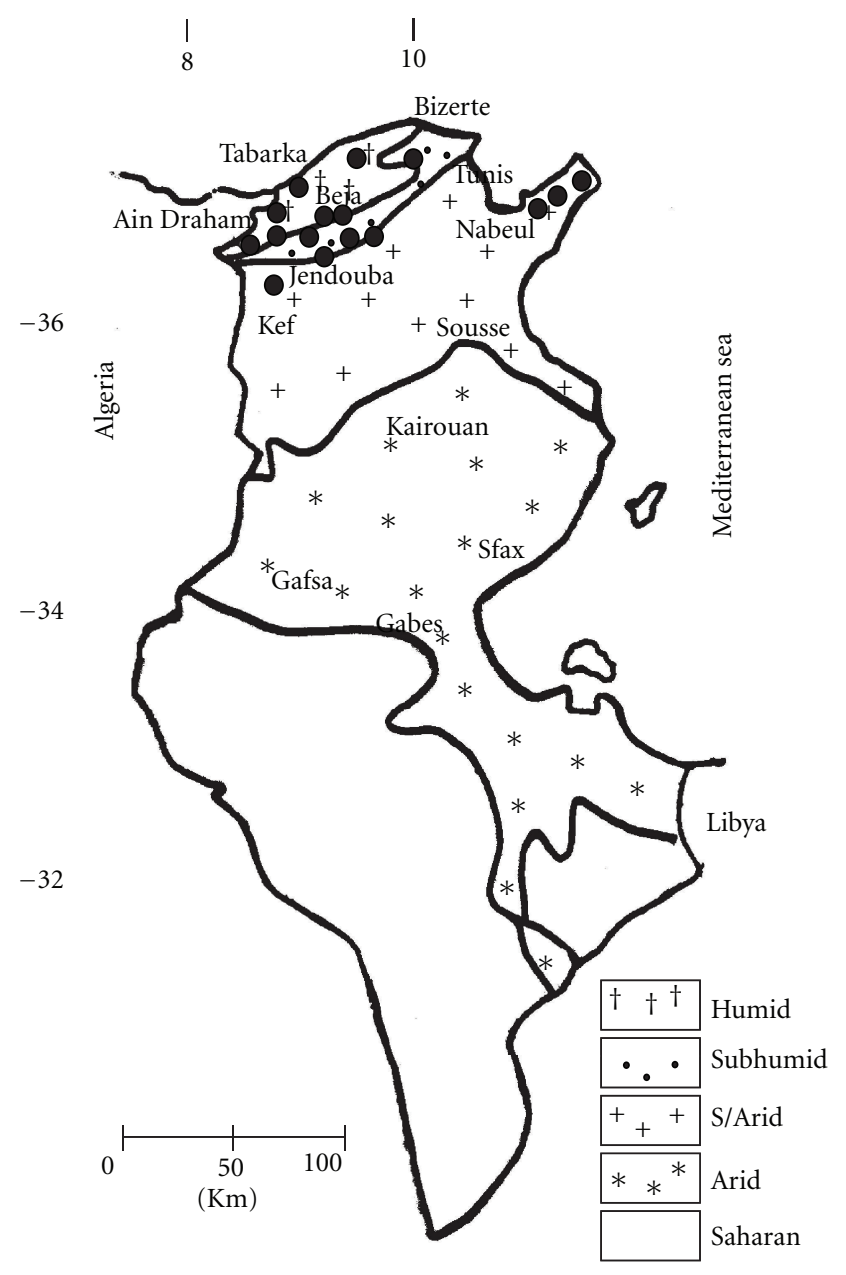

FIgURE 1: Map of Tunisia showing collection sites • of tall fescue.

population $\mathrm{X}$ year interaction was significant $(P<.001)$ for all. This demonstrates that populations responded differently to variations in environmental conditions, mainly rainfall, which varied from one year to another. In fact, the mean values of the studied traits were greater in the year 2004-2005 compared to 2005-2006 and 2006-2007 (with annual rainfall of 1360, 903 and $909 \mathrm{~mm}$, resp.). Results are in agreement with previous data exhibiting the relationships among agronomic traits influenced by genotype and environment [7]. Water available over the crop cycle is the main determinant of the variation both in environment main effects and GE interaction effects [15].

The principal component analysis provides a graphic summary of the set of agronomic measurements. Variables related to panicle size (PW, SN, PS, and TP) were highly and positively correlated (0.534-0.862) (Table 2$)$. These variables contribute to seed production. In the case of forage production, the plant height $(\mathrm{PH})$ and dry matter yield (MY) gave a high positive correlation $(+0.743)$. Spikelet number per panicle (SN) and total weight of panicles (PW), however, were negatively correlated with plant height $(\mathrm{PH})$. This indicates traits that favor seed production are opposite to forage 
TABLE 1: Description of agroecological parameters at the collection sites of each accession.

\begin{tabular}{|c|c|c|c|c|c|c|c|c|c|}
\hline Code & $\begin{array}{c}\text { Population } \\
\text { Site }\end{array}$ & Altitude (m) & Rainfull (mm) & $\operatorname{Max} \mathrm{T}^{\circ} \mathrm{C}$ & $\operatorname{Min} \mathrm{T} .{ }^{\circ} \mathrm{C}$ & Slope incline & $\begin{array}{l}\text { Anthropogenic } \\
\text { disturbances }\end{array}$ & $\mathrm{pH}$ & Soil texture \\
\hline $\mathrm{Sk}_{1}$ & Skalba & 6 & 425 & 29.5 & 8.6 & 2 & 2 & 8.50 & 3 \\
\hline $\mathrm{Sk}_{2}$ & Skalba & 18 & 425 & 29.5 & 8.6 & 1 & 2 & 8.50 & 3 \\
\hline Am & Ain melliti & 580 & 575 & 33.4 & 4.9 & 2 & 2 & 8.75 & 3 \\
\hline $\operatorname{Ad}_{1}$ & Amdoun & 335 & 650 & 35.6 & 5.2 & 3 & 2 & 8.50 & 3 \\
\hline $\mathrm{Ad}_{2}$ & Amdoun & 197 & 650 & 35.2 & 5.2 & 1 & 2 & 8.50 & 3 \\
\hline Do & Dougga & 510 & 525 & 35.2 & 5.1 & 2 & 2 & 8.75 & 3 \\
\hline $\mathrm{Nf}$ & Nefza & 30 & 700 & 32.5 & 7.7 & 1 & 2 & 9.25 & 3 \\
\hline Th & Thibar & 293 & 600 & 35.2 & 5.7 & 1 & 2 & 9.00 & 3 \\
\hline $\mathrm{Bj}$ & Béja & 170 & 226 & 31.8 & 6.7 & 1 & 2 & 9.00 & 3 \\
\hline $\mathrm{Bz}_{1}$ & Bizerte & 5 & 600 & 31.8 & 6.7 & 1 & 2 & 9.00 & 3 \\
\hline $\mathrm{Bz}_{2}$ & Bizerte & 14 & 600 & 31.8 & 6.7 & 1 & 2 & 9.50 & 3 \\
\hline $\mathrm{Bz}_{3}$ & Bizerte & 22 & 600 & 31.8 & 6.7 & 1 & 2 & 9.25 & 2 \\
\hline $\mathrm{Sd}_{1}$ & Sedjnene & 116 & 650 & 32.5 & 7.7 & 1 & 2 & 6.75 & 3 \\
\hline $\mathrm{Sd}_{2}$ & Sedjnane & 99 & 650 & 32.5 & 7.7 & 1 & 2 & 8.50 & 3 \\
\hline Ts & Teskraia & 5 & 600 & 31.8 & 6.7 & 1 & 2 & 8.75 & 3 \\
\hline $\mathrm{Sn}_{1}$ & Sidi Nsir & 75 & 500 & 23.4 & 11.9 & 1 & 2 & 8.75 & 3 \\
\hline $\mathrm{Sn}_{2}$ & Sidi Nsir & 147 & 500 & 23.4 & 11.9 & 1 & 2 & 8.75 & 3 \\
\hline Ut & Utica & 1 & 626 & 32.1 & 6.8 & 1 & 2 & 9.00 & 3 \\
\hline $\mathrm{Ta}$ & Tahent & 75 & 500 & 23.4 & 11.9 & 1 & 2 & 8.50 & 3 \\
\hline Ao & Aouna & 270 & 600 & 23.4 & 11.9 & 1 & 2 & 9.00 & 3 \\
\hline $\mathrm{Sm}$ & Sidi Mechrig & 65 & 650 & 31.8 & 6.7 & 1 & 2 & 5.00 & 2 \\
\hline $\mathrm{Tb}_{1}$ & Tabarka & 12 & 1029 & 30.2 & 8.0 & 1 & 7 & 6.50 & 2 \\
\hline $\mathrm{Tb}_{2}$ & Tabarka & 56 & 1000 & 33.4 & 4.9 & 3 & 2 & 6.50 & 2 \\
\hline $\mathrm{Tb}_{3}$ & Tabarka & 40 & 1100 & 30.2 & 8.0 & 1 & 2 & 6.50 & 2 \\
\hline $\mathrm{Fr}_{1}$ & Fernana & 315 & 800 & 30.2 & 8.0 & 3 & 2 & 9.25 & 3 \\
\hline $\mathrm{Fr}_{2}$ & Fernana & 400 & 1000 & 33.2 & 5.5 & 3 & 2 & 8.00 & 2 \\
\hline $\mathrm{Fr}_{3}$ & Fernana & 408 & 800 & 32.5 & 7.7 & 2 & 2 & 8.75 & 3 \\
\hline $\mathrm{Rr}_{1}$ & Rass rajel & 29 & 1000 & 27.5 & 8.7 & 1 & 2 & 5.25 & 2 \\
\hline $\mathrm{Rr}_{2}$ & Rass rajel & 20 & 1030.2 & 27.5 & 8.7 & 1 & 2 & 8.50 & 3 \\
\hline $\mathrm{Dr}$ & Ain Draham & 155 & 1534 & 31.3 & 3.9 & 3 & 2 & 9.00 & 3 \\
\hline Bs & Bou salem & 150 & 425 & 35.6 & 5.2 & 1 & 2 & 9.50 & 3 \\
\hline $\mathrm{Bu}$ & Bulla regia & 150 & 523 & 33.4 & 4.9 & 1 & 2 & 9.00 & 3 \\
\hline $\mathrm{Hb}$ & Hammam Bourguiba & 560 & 1200 & 31.3 & 3.9 & 3 & 2 & 6.25 & 3 \\
\hline Gh & Ghardimaou & 925 & 800 & 30.2 & 8.0 & 2 & 3 & 6.50 & 2 \\
\hline As & Ain sobaa & 68 & 900 & 30.2 & 8.0 & 1 & 2 & 7.75 & 2 \\
\hline VG & "Grombalia" & 100 & 480 & 30.6 & 8.2 & 1 & 1 & 8.20 & 1 \\
\hline VM & “Mornag” & 123 & 425 & 33.1 & 5.7 & 2 & 1 & 9.25 & 3 \\
\hline VJ & "Jebebina" & 300 & 350 & 34.6 & 6.7 & 1 & 1 & 7.60 & 1 \\
\hline
\end{tabular}

Slope incline: (1): 0-5\%, (2): 6-10\%, (3): 11-40\%; Anthropogenic disturbances: (1): cultivated, (2): grazed, (3): logged/cleared, (4): drained, (5): fire, (6): road-side, (7): settlement; Soil texture: (1): sand, (2): loam, (3): clay.

production. The correlation of these traits could be used in genetic improvement.

The relative contribution of each variable to the inertia explained by the first three principal components was summarized in Table 3. These three components account for $73.80 \%$ of the total variation with $40.09 \%, 22.77 \%$, and $10.93 \%$ for the first, second, and third component, respectively. The variables related to panicle size (PW, SN, PS, and TP) were highly and positively correlated with the first component; this component is defined as seed production. The second component defined by PH and MY correlated with forage production.

A pairwise plot of the first two principal components ( $62.86 \%$ of the total variance) reveals the degree of genetic diversity of the populations (Figure 2). This is well demonstrated by the large dispersion of populations originating from the same site such as Bizerte populations $\left(\mathrm{Bz}_{1}, \mathrm{Bz}_{2}\right.$, and $\left.\mathrm{Bz}_{3}\right)$. Such results demonstrate an independence from 
TABLE 2: Matrix of correlation between agronomic characters.

\begin{tabular}{lccccccc}
\hline & PL & PW & SN & PS & TP & SW & PH \\
\hline PL & +1.000 & & & & & & \\
PW & $+0.404^{*}$ & +1.000 & & & & & \\
SN & +0.295 & $+0.787^{* *}$ & +1.000 & & & & \\
PS & $+0.615^{* *}$ & $+0.654^{* *}$ & $+0.602^{* *}$ & +1.000 & & & \\
TP & $+0.488^{* *}$ & $+0.862^{* *}$ & $+0.670^{* *}$ & $+0.534^{* *}$ & +1.000 & & \\
SW & $+0.322^{*}$ & $+0.327^{*}$ & +0.210 & $+0.433^{*}$ & +0.301 & +1.000 & +1.000 \\
PH & +0.157 & -0.224 & -0.123 & +0.110 & -0.296 & +0.074 & $+0.743^{* *}$ \\
MY & +0.034 & -0.023 & +0.032 & +0.145 & -0.107 & +0.245 & +1.000 \\
SY & +0.126 & -0.087 & -0.059 & +0.112 & -0.109 & -0.058 & $+0.184+$ \\
\hline
\end{tabular}

${ }^{*}$ Significant at the .05 probability level. ${ }^{*}$ S Significant at the .001 probability level.

Agronomic traits: PL: Panicle length (cm), SW: hundred-seed weight (g), PW: panicle weight (g), SN: spikelet number per panicle, PS: panicle weight without seeds (g), TP: ten-panicle weight (g), PH: plant height at harvest (cm), SY: seed yield (T/ha), MY: dry matter yield (T/ha).

TABLE 3: Relative contribution of agronomic variables to the inertia explained by the first three axes.

\begin{tabular}{lccc}
\hline Components & Axis 1 & Axis 2 & Axis 3 \\
\hline Eigenvalue & 3.60 & 2.04 & 0.98 \\
\% of inertia & 40.09 & 22.77 & 10.93 \\
Cumulative \% & 40.09 & 62.87 & 73.80 \\
& PW $(+0.48)$ & PH $(+0.62)$ & SY $(+0.82)$ \\
Definition of axis & TP $(+0.45)$ & MY $(+0.60)$ & SW $(-0.43)$ \\
with components & PS (+0.43) & & \\
& SN $(+0.42)$ & & \\
\hline
\end{tabular}

SW: hundred-seed weight (g), PW: panicle weight (g), SN: spikelet number per panicle, PS: panicle weight without seeds (g), TP: ten-panicle weight (g), PH: plant height at harvest (cm), SY: seed yield (T/ha), MY: dry matter yield (T/ha).

the geographical origin of the plant material. Although, may assume that wild fescue populations are characterized by a large range in adaptation. Similar results were obtained in Tunisian perennial ryegrass using morphometric and agronomic traits [16].

Some adjacent populations, Sejnane $\left(\mathrm{Sd}_{1}\right)$, Nefza $(\mathrm{Nf})$, Tabarka $\left(\mathrm{Tb}_{3}\right.$ and $\left.\mathrm{Tb}_{1}\right)$, Sidi $\mathrm{Ncir}\left(\mathrm{Sn}_{2}\right)$, and Bizerte $\left(\mathrm{Bz}_{3}\right)$, are very close to control cultivars and seem to be characterized by forage yield. Some others as Skalba $\left(\mathrm{Sk}_{1}\right.$ and $\left.\mathrm{Sk}_{2}\right)$, Ghardimaou (Gh), Ain Sobaa (As), and Sidi Mechrig (Sm) are quite distant from control cultivars and seem characterized by greater seed production.

This analysis also reveals populations as Bizerte $\left(\mathrm{Bz}_{2}\right)$, Sidi Nsir $\left(\mathrm{Sn}_{1}\right)$, and Rass Rajel $\left(\mathrm{Rr}_{1}\right)$, which represents not only an important seed production but also a substantial forage yields. This demonstrates that these populations have a higher agronomic potential. These populations will be usable in a selection program to improve tall fescue for the North of Tunisia.

In order to explain the interaction between population and location, factorial correspondence analysis (FCA) was used taking into account agronomic traits which are an indication of the ecological characteristics of their site of origin. Highly negative correlations were detected between

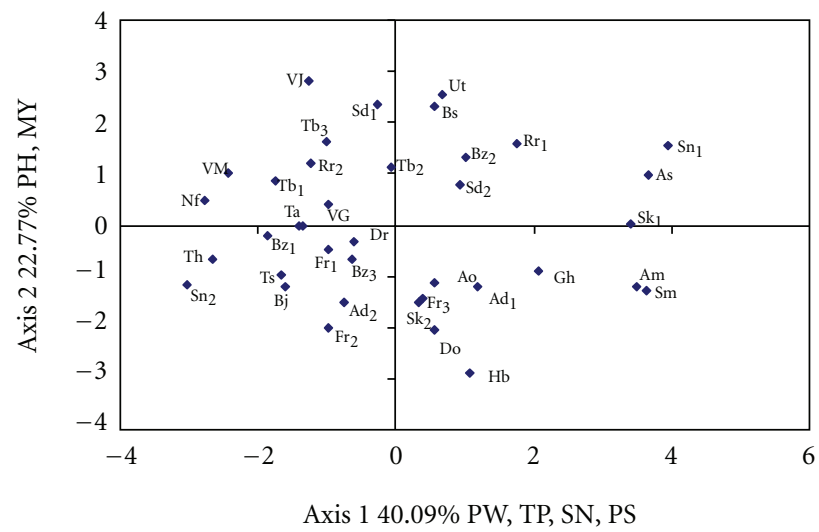

FIGURE 2: First 1-2 plan of the principal component analysis performed on 35 spontaneous populations and 3 cultivars of tall fescue and based on 9 agronomic variables. Populations and parameters abbreviations are summarized in Table 1 and Table 2, respectively.

plant height $(\mathrm{PH})$ and altitude $(\mathrm{AL})(-0.394)$ and between spikelet number per panicle (SN) and soil texture (ST) $(-0.359)$ (Table 4$)$. These results reflect the influence of altitude and soil texture on forage production and seed yield, respectively. Moreover, highly positive correlations between minimum temperature (mT), length of panicles $(\mathrm{PL})(+0.34)$ and weight of panicles without seeds (PS) $(+0.309)$, were observed reflecting the influence of minimum temperature on the architecture of plants without influence on seed yield $(-0.07)$. These results are consistent with those reported for North African tall fescue that was tested in Australia [17]. An example of the relationship between ecological characteristics and agronomic traits is exhibited by perennial ryegrass vigour when grown under average July temperatures [18]. In addition, relationships among agronomic traits in oat genotypes grown in different environments in three consecutive years (1999-2001) indicate that genotype and environment are major determinants of plant phenotype [7]. Similar results exist between adaptation and agronomic potentials of Azolla plants in the climate of Mediterranean regions [19]. 
TABLE 4: Correlations between agronomic characters and pedoclimatic factors of tall fescue.

\begin{tabular}{lcccccccc}
\hline & $\mathrm{AL}$ & $\mathrm{AD}$ & $\mathrm{SI}$ & $\mathrm{ST}$ & $\mathrm{RF}$ & $\mathrm{PH}$ & $\mathrm{TM}$ & $\mathrm{mT}$ \\
\hline PL & -0.181 & +0.038 & -0.130 & -0.059 & -0.007 & -0.035 & -0.273 & $+0.340^{*}$ \\
PW & +0.178 & -0.032 & +0.261 & -0.131 & 0.113 & -0.292 & -0.211 & +0.138 \\
SN & +0.235 & -0.051 & +0.156 & $-0.359^{*}$ & +0.129 & $-0.330^{*}$ & +0.012 & -0.041 \\
PS & -0.136 & -0.037 & -0.070 & -0.250 & +0.004 & -0.207 & -0.278 & $+0.309^{*}$ \\
TP & +0.146 & -0.012 & +0.084 & -0.030 & -0.015 & -0.242 & -0.164 & +0.106 \\
SW & -0.007 & +0.229 & +0.007 & -0.069 & +0.097 & -0.249 & -0.028 & +0.093 \\
PH & $-0.394^{* *}$ & -0.241 & $-0.310^{*}$ & -0.161 & -0.131 & +0.026 & -0.079 & +0.225 \\
MY & -0.130 & -0.185 & +0.059 & -0.223 & -0.061 & -0.090 & +0.053 & +0.051 \\
SY & -0.287 & +0.222 & +0.221 & -0.053 & +0.306 & +0.008 & +0.009 & -0.077 \\
\hline
\end{tabular}

* Significant at the .05 probability level. ** Significant at the .01 probability level.

Agronomic traits: PL: panicle length (cm), SW: hundred-seed weight (g), PW: panicle weight (g), SN: spikelet number per panicle, PS: panicle weight without seeds (g), TP: ten-panicle weight (g), PH: plant height at harvest (cm), SY: seed yield (T/ha), MY: dry matter yield (T/ ha).

eco-edaphic factors: AL: altitude (m), RF: rainfall (mm), SI: slope incline (\%), AD: anthropogenic disturbances, pH: $\mathrm{pH}, \mathrm{ST}$ : soil texture (\%), mT: minimum temperature $\left({ }^{\circ} \mathrm{C}\right)$, MT: maximum temperature $\left({ }^{\circ} \mathrm{C}\right)$.

The plan 1-2 of the factorial correspondence analysis (FCA), based on agronomic characters and pedoclimatic factors, explains $95.52 \%$ of the total variability (Figure 3 ). The populations of Tabarka $\left(\mathrm{Tb}_{1}, \mathrm{~Tb}_{2}\right.$, and $\left.\mathrm{Tb}_{3}\right)$ and Rass Rajel $\left(\mathrm{Rr}_{1}\right.$ and $\left.\mathrm{Rr}_{2}\right)$ are mutually associated with an important rainfall. Otherwise, the populations of Ghardimaou (Gh), Ain melliti (Am), and Dogga (Do) are essentially attributed to altitude. Similar results were obtained within Tunisian perennial ray-grass populations collected from the same sites [20]. In addition, the microgeographical differentiations were reported in perennial ryegrass [10]. Previous data reported the important variability of agronomic characters elucidating intersites differences in performance $[21,22]$.

An overlapping of most of the agronomic and pedoclimatic variables characterizes the two cultivars "Grombalia" and "Mornag" and particularly the populations of Bizerte area $\left(\mathrm{Sn}_{1}\right.$, and $\left.\mathrm{Bz}_{2}\right)$. These populations, characterized by forage yield and high seed production, will be suitable for use in a tall fescue breeding and valorization program in Tunisia.

\section{Conclusion}

The agronomic study performed on 35 spontaneous populations of tall fescue collected from the North of Tunisia, and three local cultivars, revealed important genetic diversity. Results indicate that Tunisian tall fescue constitutes a considerable phylogenetic patrimony with good potential for improving pastoral lands. Multivariate analysis provided evidence that populations are clustered independently from their geographic origin offering a large dispersion of populations originating from the same site as observed for Bizerte populations. Results allowed the characterization of the different populations: first, great similarities were detected between the cultivars and several spontaneous populations (Sejnane $\left(\mathrm{Sd}_{1}\right)$, Nefza (Nf), Tabarka $\left(\mathrm{Tb}_{3}\right)$, Sidi Nsir $\left(\mathrm{Sn}_{2}\right)$, and Bizerte $\left.\left(\mathrm{Bz}_{3}\right)\right)$, reflecting their positive agronomic attributes; second, the populations Skalba $\left(S_{1}\right.$ and $\left.S k_{2}\right)$, Ghardimaou (Gh), Ain Sobaa (As), and Sidi Mechrig (Sm) are distinguished from cultivars and characterized by greater

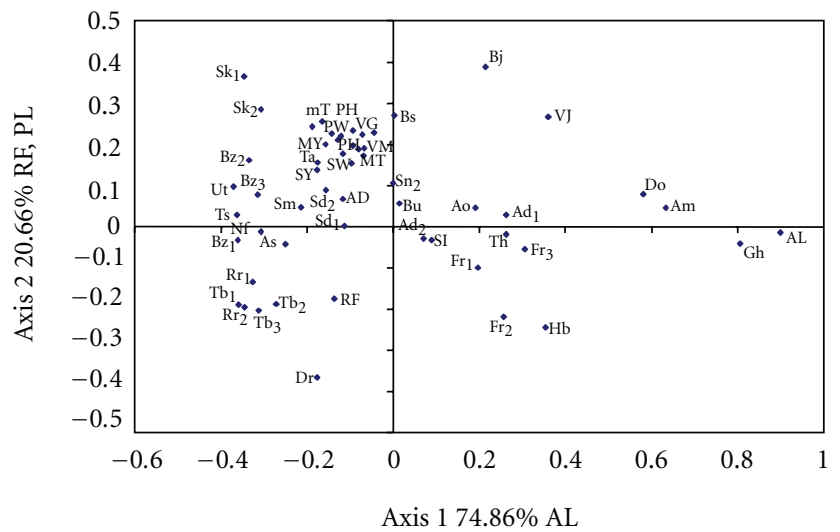

FIGURE 3: Dispersion of populations in the 1-2 plan of the factorial correspondence analysis based on agronomic characters and pedoclimatic factors. Populations and parameters abbreviations are summarized in Tables 1 and 2, respectively.

seed production, and third, Bizerte $\left(\mathrm{Bz}_{2}\right)$, Sidi $\mathrm{Nsir}\left(\mathrm{Sn}_{1}\right)$, and Rass Rajel $\left(\mathrm{Rr}_{1}\right)$ have a greater agronomic potential with both seed production and substantial forage yield components.

The interaction of pedoclimatic factors and agronomic characters were revealed, especially between altitude, soil texture, and minimum temperature, respectively, with forage production, seed yield, and the plants architecture. The influence of pedoclimatic factors on populations structure is primarily rainfall for the populations of Tabarka $\left(\mathrm{Tb}_{1}, \mathrm{~Tb}_{2}\right.$, and $\left.\mathrm{Tb}_{3}\right)$ and Rass Rajel $\left(\mathrm{Rr}_{1}\right.$ and $\left.\mathrm{Rr}_{2}\right)$, and altitude, for the populations of Ghardimaou (Gh), Ain melliti (Am) and Dogga (Do). In fact, with regard to their agronomic characteristics, Bizerte $\left(\mathrm{Bz}_{2}\right)$ and Sidi Nsir $\left(\mathrm{Sn}_{1}\right)$ appear to be wild spontaneous fescue populations characterized by wide adaptation. Indeed, all results showed that spontaneous populations Bizerte $\left(\mathrm{Bz}_{2}\right)$, Sidi Nsir $\left(\mathrm{Sn}_{1}\right)$ and Rass Rajel $\left(\mathrm{Rr}_{1}\right)$, which possess important agronomic potentials, will be suitable for use in a selection program to improve tall fescue in the North of Tunisia. 


\section{Acknowledgment}

This work was partially supported by grants from the Tunisian "Ministère de l'Enseignement Supérieur, de la Recherche Scientifique": "Projet LR B02."

\section{References}

[1] A. Cuenod, G. Poittier-Alapetite, and A. Labbe, "Cryptogames vasculaires, gymnospermes et monocotylédones," Flore analytique et synoptique de la Tunisie, Imp. S.E.F.A.T. Tunis, 1954.

[2] P. J. Cunningham, W. L. Graves, M. Chakroun et al., "Novel perennial forage germplasm from North Africa and Sardinia," Australian Plant Introduction Review, vol. 27, pp. 13-46, 1997.

[3] W. Xu, D. A. Sleper, and D. A. Hoisington, "A survey of restriction fragment length polymorphisms in tall fescue and its relatives," Genome, vol. 34, no. 5, pp. 686-692, 1991.

[4] E. Terrell, "Taxonomy, morphology and phylogeny," in Tall Fescue, R. C. Buckner and L. P. Bush, Eds., pp. 31-39, Crop Sci. Soc. America, Madison, Wis, USA, 1979.

[5] D. A. Sleper and C. P. West, "Tall fescue," in Cool Season Grasses, L. E. Moser, D. R. Buxton, and M. D. Cassler, Eds., pp. 471-502, American Society of Agronomy, Madison, WI, 1996.

[6] G. M. Evans, K. H. Asay, and R. G. Jenkins, "Meiotic irregularities in hybrids between diverse genotype of tall fescue (Festucae arundinacea Schreb.)," Crop Science, vol. 13, pp. 373379, 1973.

[7] D. M. Peterson, D. M. Wesenberg, D. E. Burrup, and C. A. Erickson, "Relationships among agronomic traits and grain composition in oat genotypes grown in different environments," Crop Science, vol. 45, no. 4, pp. 1249-1255, 2005.

[8] J. I. Bradshaw, "Population differentiation in Agrostis tenuis I. Morphological differentiation," New Phytologist, vol. 58, pp. 208-227, 1959.

[9] B. F. Tyler and K. H. Chorlton, "Characterisation of perennial ryegrass ecotypes from eastern France and Switzerland," Welsh Plant Breeding Station, Aberystwyth, pp. 43-46, 1978.

[10] G. Charmet and F. Balfourier, "Influence of ecological factors on population differentiation in perennial ryegrass (Lolium perenne L.)," Genetic Resources and Crop Evolution, vol. 41, no. 3, pp. 175-184, 1994.

[11] F. Balfourier, J. A. Oliveira, G. Charmet, and E. Arbones, "Factorial regression analysis of genotype by environment interaction in ryegrass populations, using both isozyme and climatic data as covariates," Euphytica, vol. 98, no. 1-2, pp. 3746, 1997.

[12] M. Sahramaa, L. Hömmö, and L. Jauhiainen, "Variation in seed production traits of reed canarygrass germplasm," Crop Science, vol. 44, no. 3, pp. 988-996, 2004.

[13] SAS, SAS User's Guide, version 6.07, SAS Institute, Cary, NC, USA, 4th edition, 1990.

[14] J. P. Benzecri, L'analyse des données II. L'analyse des correspondances, Dunod, Paris, France, 1973.

[15] P. Annicchiarico, A. Abdelguerfi, M. Ben Younes et al., "Adaptation of sulla cultivars to contrasting Mediterranean environments," Australian Journal of Agricultural Research, vol. 59, no. 8, pp. 702-706, 2008.

[16] S. Ghariani, N. Trifi-Farah, M. Chakroun, S. Marghali, and M. Marrakchi, "Morphological characterization of Tunisian perennial reygrass germplasm," Journal of Genetics and Breeding, vol. 57, no. 2, pp. 185-190, 2003.
[17] K. F. M. Reed, "Improving the adaptation of perennial ryegrass, tall fescue, phalaris, and cocksfoot for Australia," New Zealand Journal of Agricultural Research, vol. 39, no. 4, pp. 457-464, 1996.

[18] G. Charmet, A. Bion, and F. Balfourier, "Agronomic evaluation of perennial ryegrass wild populations from Ireland for use in French plant breeding programmes," Agronomie, vol. 9, pp. 985-991, 1989.

[19] M. N. Gevrek, B. Samanci, B. Yağmur, O. Arabaci, and E. Özkaynak, "Studies on the adaptation of Azolla mexicana in the Aegean and the Mediterranean regions," Plant Production Science, vol. 7, no. 1, pp. 50-54, 2004.

[20] S. Ghariani, M. Chakroun, N. Trifi-Farah, S. Marghali, and M. Marrakchi, "Evaluation agronomique d'une collection de populations tunisiennes de Lolium perenne L," Fourrages, vol. 177, pp. 125-134, 2004.

[21] L. A. Edye, R. L. Burt, W. T. Williams, R. J. Williams, and B. Grof, "A preliminary agronomic evaluation of Stylosanthes species," Australian Journal of Agricultural Research, vol. 24, no. 4, pp. 511-525, 1973.

[22] B. S. Dear, G. A. Moore, and S. J. Hugues, "Adaptation and potential contribution of temperate perennial legumes to the southern Australia wheatbelt," Australian Journal of Agricultural Research, vol. 43, pp. 1-18, 2003. 


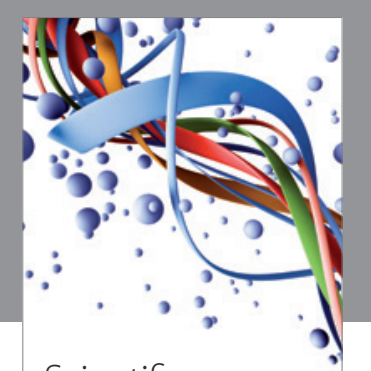

Scientifica
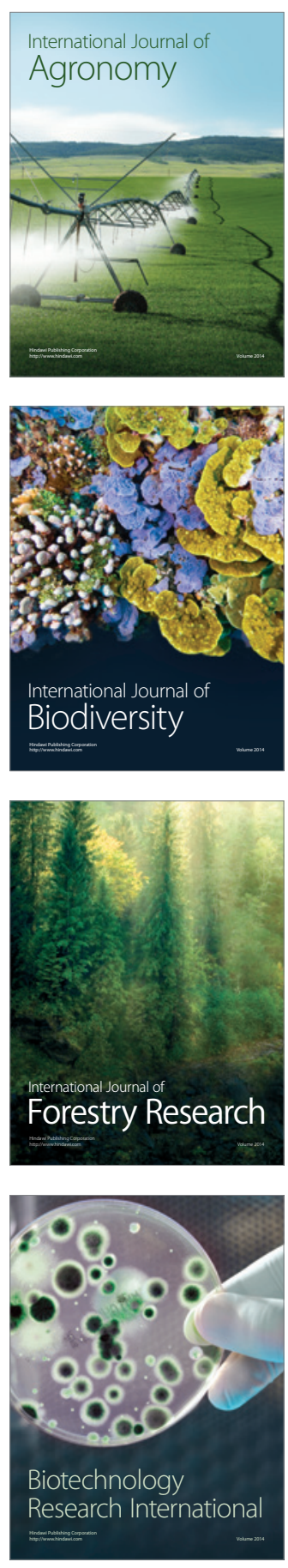
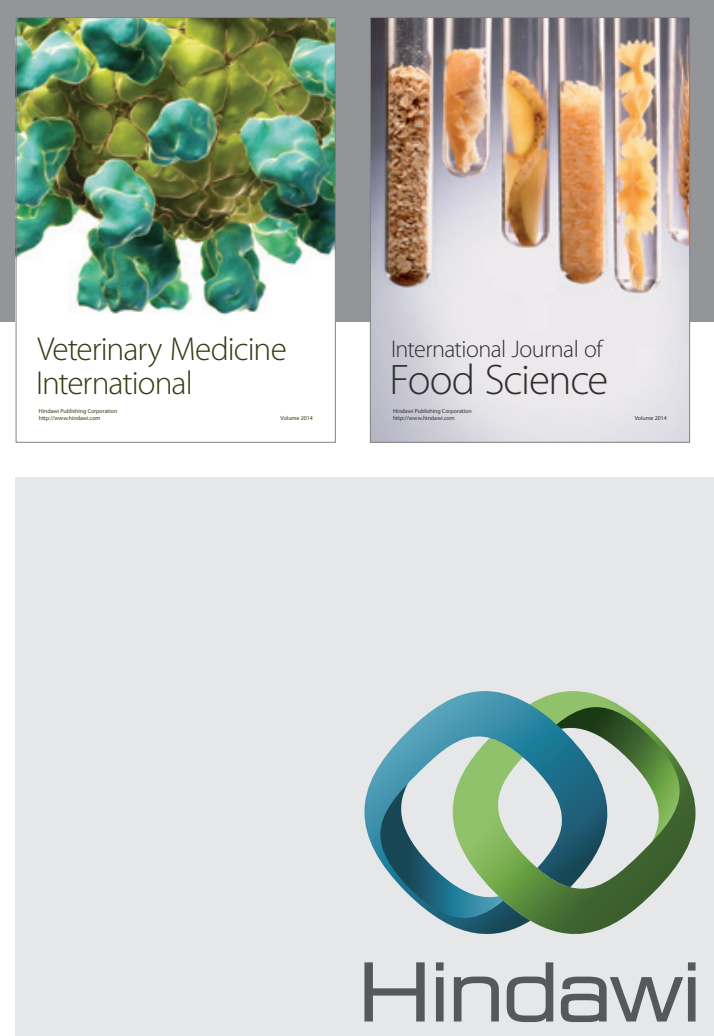

Submit your manuscripts at

http://www.hindawi.com
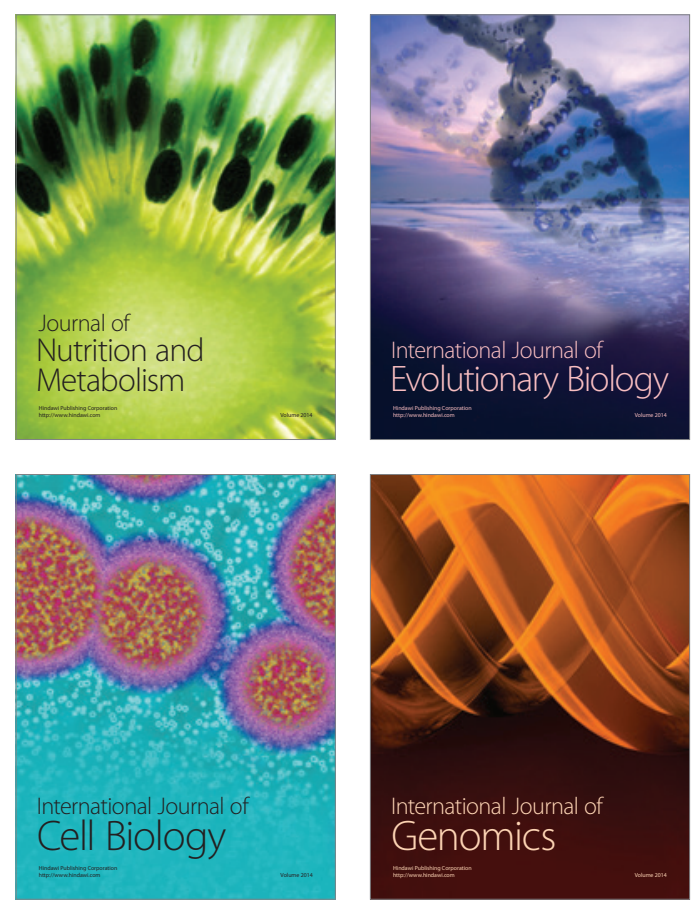
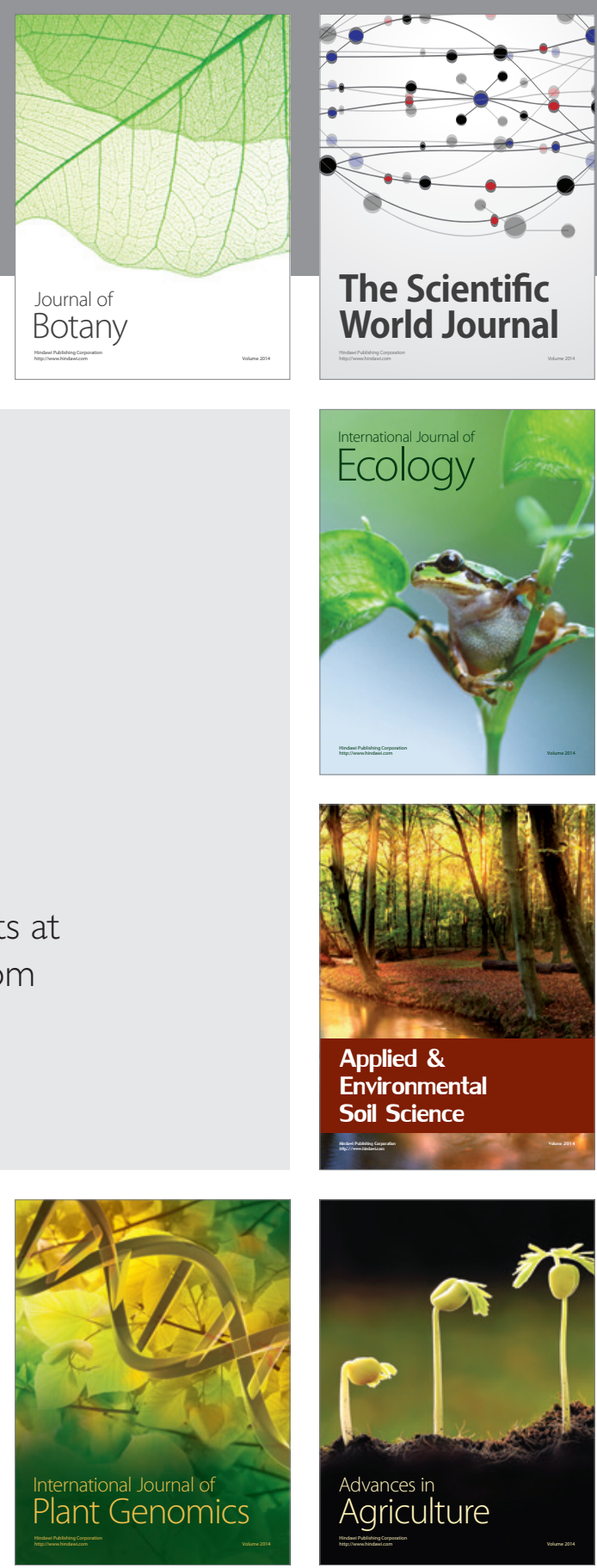

The Scientific World Journal
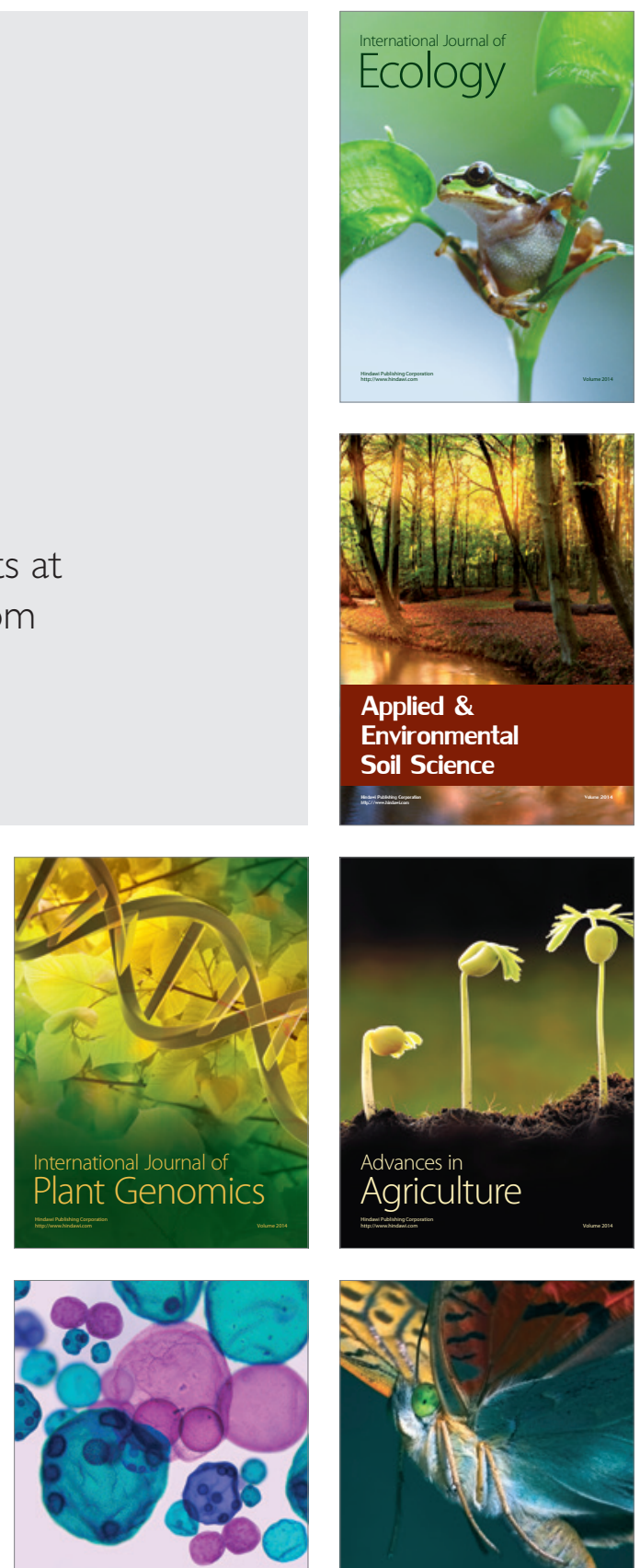

International Journal of Microbiology

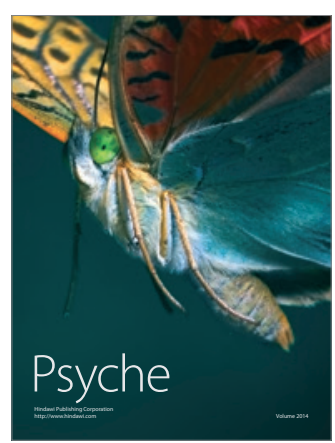

